\title{
IAMJ
}

INTERNATIONAL

AYURVEDIC

MEDICAL JOURNAL

\section{EFFICACY OF ASHWAGANDHA AND YASHTIMADHU VATI WITH SHARKARAYUKTA DUGDHA IN INTRAUTERINE GROWTH RETARDATION (IUGR)}

\section{Preeti Pimpalshende ${ }^{1}$, Mrudula B. Kulkarni ${ }^{2}$}

${ }^{1}$ Assistant Professor, Department of Stree rog and Prasuti Tantra, Bhausaheb Mulak Ayurved College and Research hospital, Butibori, Nagpur, Maharashtra, India

${ }^{2}$ Assistant Professor, Department of Stree rog and Prasuti Tantra, Bharti Vidyapeeth college of Ayurved, Pune, Maharashtra, India

Corresponding Author: kombeys.pooja@gmail.com

\section{https://doi.org/10.46607/iamj1009072021}

(Published Online: July 2021)

Open Access

(C) International Ayurvedic Medical Journal, India 2021

Article Received: 30/06//2021 - Peer Reviewed: 05/07/2021 - Accepted for Publication: 09/07/2021

\section{Check for updates}

\section{ABSTRACT}

Background and Objective: To study the Efficacy of Ashwagandha and Yashtimadhu Vati with Sharkarayukta Dugdha in Intra-Uterine Growth Retardation (IUGR) and to see the side effects and adverse effects of Ashwagandha \& Yashtimadhu during treatment. Methodology: The research was carried out at the Prasuti Avum StreeRoga Vibhag of Bharati Vidyapeeth's Ayurved Hospital, Dhankawadi, Pune 43. In the clinical randomized study, a total of 25 patients, where they received Ashwagandha-2 BD (each vati 500mg) Yashtimadhu - 1 BD (each vati 500mg) with Sharkarayuktadugdhaand follow up after every 7 days for 1 month. Results: Comparing the assessment criteria before and after treatment, it was seen that there was significant action on IUGR. Treatment had no adverse effects in a clinical trial. Statistical Analysis: As per statistical analysis, Ashwagandha and Yashtimadhu Vati with Sharkarayukta Dugdha showed a significant effect. Conclusion: 1. In the present study, it has been proved that Ashwagandha Vati and Yashtimadhu Vati with Sharkarayukta Dugdha had a good effect on IUGR. 2. No adverse and side effects were found during or after the treatment neither on the mother nor on the fetus. 
Keywords: Ayurveda treatment, IUGR.

\section{INTRODUCTION}

In pregnancy sometimes due to Mithya-ahar-vihar, overexertion, stress \& malnutrition, women suffer from various problems. These are Yonigatastrava, Udarshoola or growth of fetus get retarded etc. Intra Uterine Growth Retardation [IUGR] is one of the important symptoms observed in day-to-day practice. According to modern science, IUGR is a common disorder in obstetrics \& carries an increased risk of perinatal mortality \& morbidity. Identification of IUGR is crucial. Proper evaluation \& management can result in a favourable outcome. Babies are born with a wide range of birth weights, but the focus is on babies who appear to be small for gestational age. Certain pregnancies are at high risk for growth restriction, although a substantial percentage of cases occur in the general obstetric population. Accurate dating early in pregnancy is essential for a diagnosis of IUGR. Ultrasound biometry is the gold standard for the assessment of the fetal size and the amount of amniotic fluid. Serial ultra-sonograms are important for monitoring growth restriction and management. Fetal growth restriction is the second leading cause of perinatal morbidity and mortality, followed only by prematurity. The incidence of IUGR is estimated to be approximately $5 \%$ in the general obstetric population. In assessing perinatal outcome by weight, infants who weigh less than $2500 \mathrm{gms}$ at term have a perinatal mortality rate 5-30 times greater than that of infants whose birth weight are at the 50th percentile of normal weight. The mortality rate is $70-100$ times higher in infants who weigh less than 1500 gms. Perinatal asphyxia involving multiple organ systems is one of the most significant problems in growthrestricted infants.

Low birth weight due to IUGR is prone to so many infections. These babies are having less immunity as compared to full-term normal weighing babies. According to Ayurveda if a pregnant woman does not follow the recommendations from Ayurveda, she may land up into many pregnancy-related complications which are broadly categorized as
"Garbhavyapada" \& "Garbhaupadrava". Garbhavyapada is disorders of Garbha/foetus like Garbhastrava (early pregnancy loss), Garbhapaata (2nd-trimester abortion), Garbhashosha, Upavishtaka, Nagodara, Leenagarbha (various types of IUGR) and Mritagarbha (IUD). There are certain management advised in Ayurvedic texts for such IUGR conditions. According to Charakasamhita and Bhavprakash Nighantu references, Ashwagandha, Yashtimadhu, Sharkara and Dugdha, these dravyas are selected for the study.

\section{NEED OF THE STUDY}

The disorders of fetal growth have a bearing on the future life of the child. This has been emphasized in the fetal origin of adult diseases. The babies who are underweight at the time of delivery are more likely to suffer from disorders like DM, MI, and Arthritis etc. in their early adulthood than the babies having normal weight. So, the quality of future life is severely compromised due to IUGR. To validate the role of Ayurvedic formulations in the prevention and management of growth retardation this subject was chosen. Ayurvedic formulations for IUGR, if found to be effective, can provide a safe, reliable and economical alternative to the available mode of management.

\section{AIM}

To study the efficacy of Ashwagandha, Yashtimadhu, SharkarayuktaDugdha when used in combination in IUGR.

\section{OBJECTIVES -}

1. To study literacy of Garbhashosha\& other types of growth restriction in Ayurveda texts.

2. To study the modern aspect of IUGR.

\section{MATERIAL \& METHODOLOGY -}

Study Design: This was an experimental clinical study.

1] Place of Research - The research has been carried out at the Prasutitantra Avum Striroga Vibhag of Bharati Vidyapeeth's Ayurved Hospital, Dhankawadi, Pune -43 . $\square 25$ cases have been taken from Bharati Ayurved Hospital according to model case paper. 
Complete general and systemic examinations of the patient have been done. - Consent for treatment has been taken from each patient. a) 25 patients have received Ashwagandha - 2 BD (each Vati 500mg) Yashtimadhu - 1 BD (each Vati 500mg) with Sharkarayukta dugdha in BD dose and follow up after every 7 days for 1 month.

\section{MATERIAL AND METHOD \\ INCLUSION CRITERIA}

1. In between 24-32 weeks IUGR patients will be selected for treatment.

2. Parity-primigravida, as well as multigravida, will be selected for treatment.

3. Patients from all socioeconomic classes visit the hospital.

4. Mild Pregnancy Induced Hypertension [PIH].

\section{EXCLUSION CRITERIA -}

1. Patients having severe maternal illness during pregnancy. (viz. cardiac disease, DM, HIV etc)

2. Fetal anomalies.

3. Uterine anomaly.

4. Severe PIH will be excluded.

\section{DISCONTINUATION CRITERIA:}

1. If there was no maternal weight gain after 2 weeks of treatment, then the drug has been discontinued.

2. If the mother has developed untoward side effects, then treatment has been discontinued.

3. Noncompliance of the patient.

4. Voluntary withdrawal by the patient.

5. If the patient was not regular for follow up then she has been discontinued.

\section{ASSESSMENT CRITERIA-}

1. Fundal height according to LMP/period of amenorrhea

2. Fetal weight according to USG and standard parameters (Shepherd's chart)

3. Abdominal circumference

4. Weight of the patient.

\section{OBJECTIVE CRITERIA}

Haemogram, blood group, BSL Random, Urine Routine and Microscopic, HIV, VDRL, HBsAg.

USG - before the commencement of treatment and after treatment or whenever necessary.
Observation (before and after treatment)

1. Maternal weight gain

2. Fundal height in $\mathrm{cm}$ from the pubic symphysis

3. Abdominal girth at the umbilicus.

4. Fetal weight on USG.

\section{MATERIALS:}

1. Collection:

a) Collection of Ashwagandha, Yashtimadhu, and Sharkara is from a reputed local market (from only one place)

b) Collection of Dugdha is from the local market.

2. Authentification: The authentification of Yashtimadhu and Ashwagandha was done at Pune University Botany Department.

3. Standardization: Late Prin. B.V. Bhide Foundation for education \& research in Chemistry, Ayurveda \& Allied Sciences

4. Preparation: The preparation of Yashtimadhu Vati and Ashwagandha Vati is made according to Vati Kalpana.

Steps in preparation of Ashwagandha Vati and YashtimadhuVati:

1. The drugs were procured from the local market.

2. The root of Ashwagandha and root of Yashtimadhu was powdered using a pulveriser and the powder was sieved using eighty mesh size sieves.

3. The tablets were prepared by the addition of excipients using the direct compression method.

4. The powder property and angle of response were noted.

5. Prepared tablets were analysed with I.P. parameters.

\section{POSOLOGY -}

a. Dose:- Ashwagandha - 2 BD (each Vati 500mg) Yashtimadhu - 1 BD (each Vati 500mg)

b. Form:- Vati

c. Anupana:- Sharkarayukta dugdha

d. Route of administration - oral

e. Time:- Twice a day[2 Vatis of Ashwagandha and 1 Vati of Yashtimadhu. Purvahanakala Ratrikala

f. Follow up:- 7th day [once a week] till completion of treatment i.e. 1 month

g. Duration of the drug:- 1 month.

Fig. no. 5 Yashtimadhu Vati 


\section{STATISTICAL ANALYSIS}

Paired T-test has been applied for the calculation of effect on the treatment of IUGR

\section{OBSERVATION -}

According to Prakruti wise distribution of patients.
The majority of IUGR cases are found in Pittavatanubandhi Prakruti i.e 36\% then $32 \%$ are found in Pitta-kaphanubandhi Prakruti.

According to the Age-wise distribution of patients. The majority of IUGR cases are found in the age group of 21-25i.e $80 \%$.

According to Parity distribution of patients.

Graph 3: According to Parity wise distribution of patient

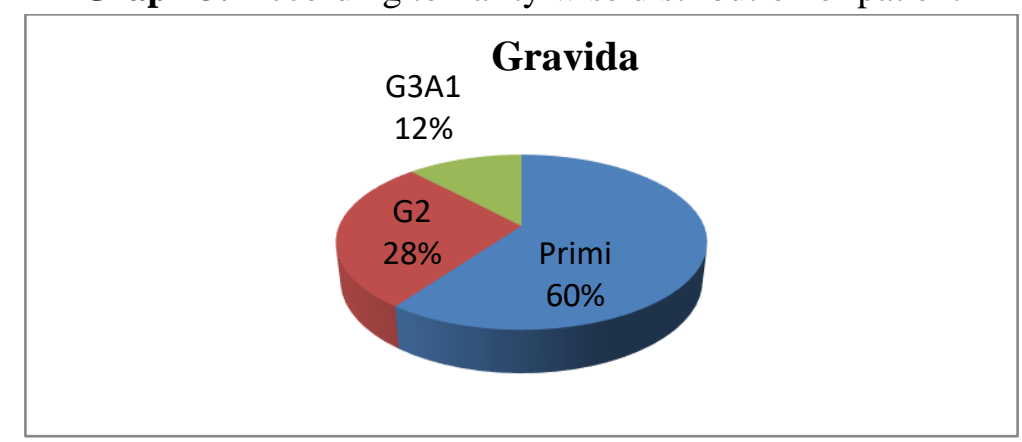

Conclusion: Majority of IUGR cases are found in Primi Para patients i.e. $60 \%$.

According to maternal weight gain wise distribution of patients.

Table B- 4: According to maternal weight gain wise distribution of patient.

\begin{tabular}{|l|l|l|l|l|l|l|l|}
\hline Maternal Weight Gain (Kgs.) & \multicolumn{2}{|l|}{ Before } & After & t-Value & P-Value & Result \\
\hline & Mean & S.D. & Mean & S.D. & & & \\
\hline & 51.57 & 6.16 & 53.79 & 6.14 & -13.954 & .000 & Significant \\
\hline
\end{tabular}

Graph 4: According to maternal weight gain wise distribution of patient.

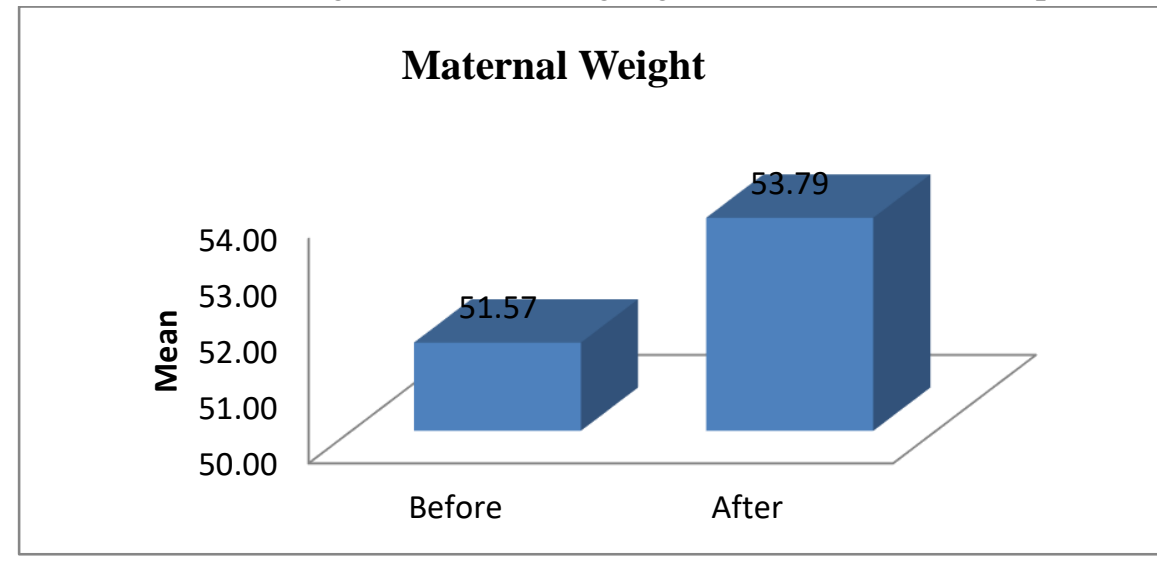

Conclusion: Using Paired t-test, we observed that P-Value is less than 0.05, we can conclude that the average maternal weight is significantly increased from 51.57 to 53.79 . 
According to the abdominal girth wise distribution of patients.

Table B-5: According to abdominal girth wise distribution of patient

\begin{tabular}{|l|l|l|l|l|l|l|l|}
\hline $\begin{array}{l}\text { ABDOMINAL } \\
\text { GIRTH (CM) }\end{array}$ & Before & After & t-Value & P-Value & Result \\
\hline & Mean & S.D. & Mean & S.D. & & & \\
\hline & 78.92 & 3.60 & 85.32 & 3.96 & -17.105 & .000 & Significant \\
\hline
\end{tabular}

Graph 5: According to abdominal girth wise distribution of patient

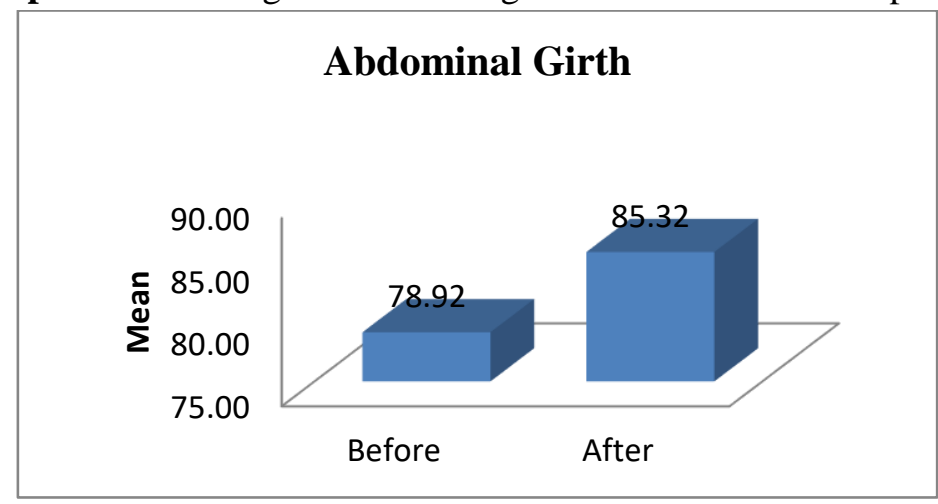

Conclusion: Using Paired t-test, we observed that P-Value is less than 0.05 , we can conclude that the average abdominal girth is significantly increased from 78.92 to 85.32 .

According to Fundal height wise distribution of patient:-

Table B-6: According to fundal height wise distribution of patient

\begin{tabular}{|l|l|l|l|l|l|}
\hline Fundal Height & Before & After & t-Value & P-Value & Result \\
\hline & 27.96 & 32.68 & -3.406 & .002 & Significant \\
\hline
\end{tabular}

Graph 6: According to fundal height wise distribution of patient

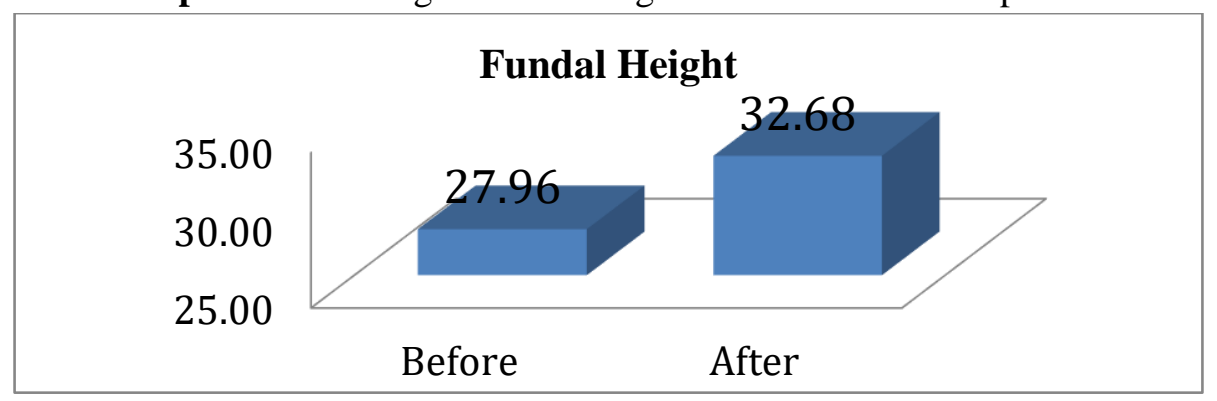

Conclusion: Using Paired t-test, we observed that P-Value is less than 0.05, we can conclude that there is a significant change in Fundal Height.

According to EFW wise distribution of patients.

Table B-7: According to EFW wise distribution of patient

\begin{tabular}{|l|l|l|l|l|l|l|l|}
\hline \multirow{2}{*}{ EFW (GM) } & Before & \multicolumn{3}{|l|}{ After } & t-Value & P-Value & Result \\
\cline { 2 - 7 } & Mean & S.D. & Mean & S.D. & & & \\
\hline & 1585.64 & 1698.48 & 1936.96 & 430.58 & 3.23 & 0.003 & Significant \\
\hline
\end{tabular}




\section{Graph 7: According to EFW wise distribution of patient}

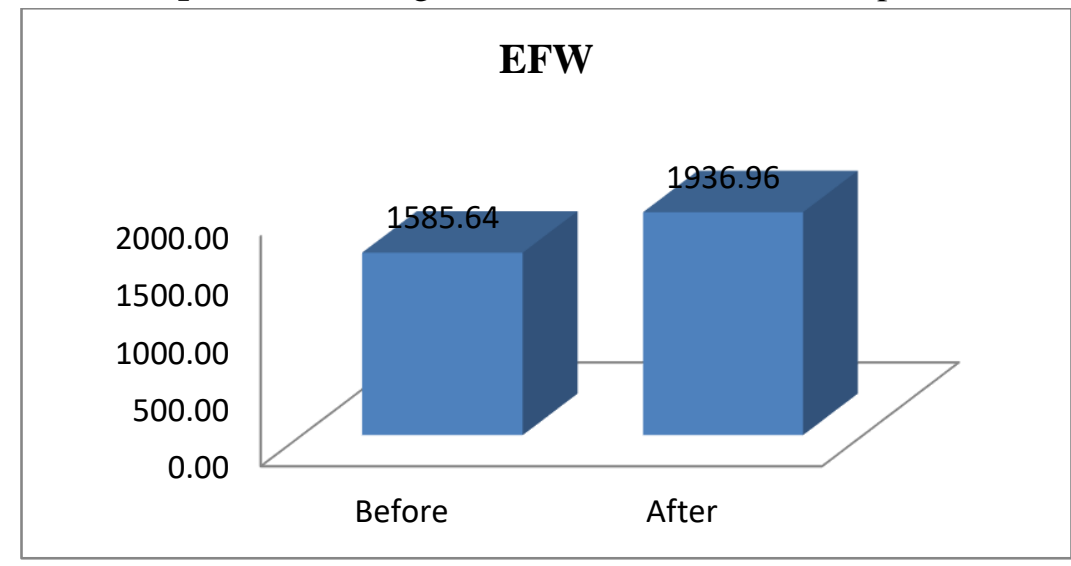

Conclusion: Using Paired t-test, we observed that P-Value is less than 0.05 , we can conclude that there is a significant change in $\mathrm{EFW}(\mathrm{gms})$.

According to the mode of delivery wise distribution of patients.

Table B-8: According to the mode of delivery wise distribution of patient According to the mode of delivery

\begin{tabular}{|l|l|l|}
\hline Normal/LSCS & Frequency & Percentage \\
\hline FIND & 17 & 67 \\
\hline LSCS & 8 & 33 \\
\hline TOTAL & 25 & 100 \\
\hline
\end{tabular}

Graph 8: According to the mode of delivery wise distribution of patient

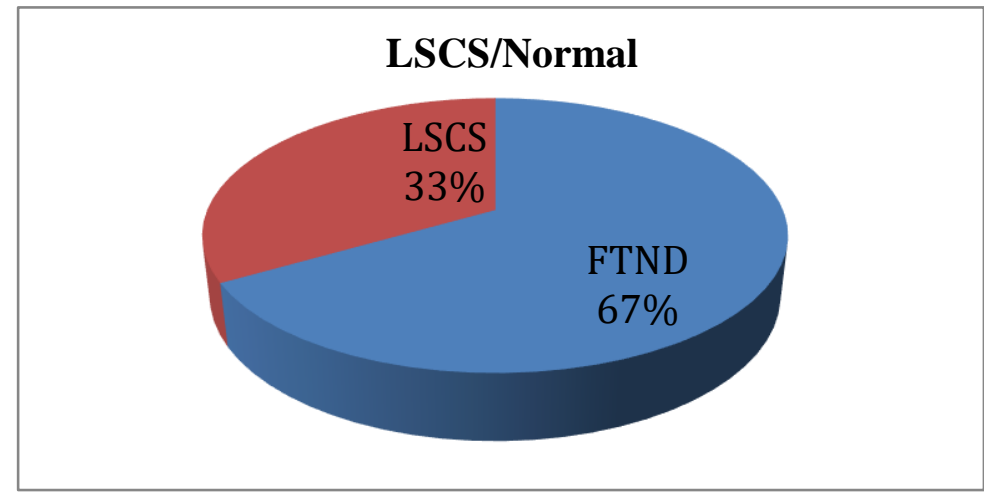

Conclusion: $\quad 66.7 \%$ fetus delivered vaginally and $33.3 \%$ were delivered via cesarean section

\section{According to Birth weight wise distribution of patients}

Table B-9: According to Birth weight wise distribution of patient

\section{BIRTH WEIGHT}

\begin{tabular}{|l|l|l|}
\hline Birth weight & Number of patients & Percentage (\%) \\
\hline$<2.5$ & 11 & 44 \\
\hline 2.5 and above & 14 & 56 \\
\hline
\end{tabular}


Graph 9: According to Birth weight wise distribution of patient

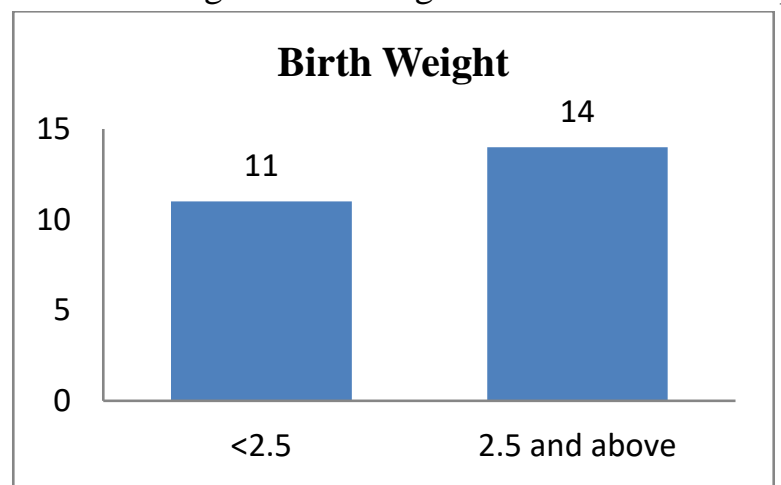

Conclusion: Out of 25 patients....

- 14 babies birth weight is equal to \& more than $2.5 \mathrm{kgs}$.

- 11 babies are having birth weights less than $2.5 \mathrm{kgs}$.

\section{Liquor status before and after treatment.}

Table B-10: Liquor status

\begin{tabular}{|l|l|l|l|}
\hline & More oligohydramnios & Oligohydramnios & Adequate \\
\hline Before treatment & 0 & 9 & 16 \\
\hline After treatment & 2 & 9 & 14 \\
\hline
\end{tabular}

Graph 10: Liquor status

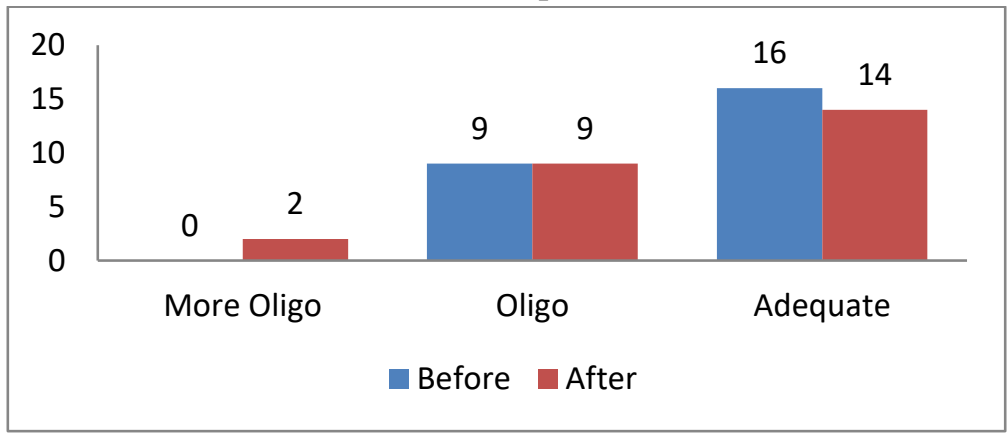

Conclusion: There was no significant effect on liquor status during Treatment.

\section{DISCUSSION}

Maximum numbers of patients were seen in the age group 21 to 25 yrs. Still in this study, this group is having $80 \%$ of the cases of IUGR.This may be because of some factors which trigger the stress e.g., career, occupation, economic condition, family problems etc. which may lead to increase stress and hence in those women it leads to IUGR.Maximum no of patients were seen Pitta-Vatanubandhi Prakruti. As because of the Hetus like change in diet, stress factors Pitta and Vata gets vitiated which further leads to
Samprapti of Upavishtak which is considered herein correlated with IUGR. Maximum IUGR incidences were found in primigravida patients i.e. $60 \%$ and $40 \%$ cases were found in multigravida. This is because of their unawareness in following the proper regime from the time of conception till Prasav. The major cause is certainly because of unawareness of pregnancy physiology, pregnancy-related dietary changes. Thus, consumption of improper diet, extreme physical and mental stress etc. are found more in primi patients. Maximum numbers of the patient 
were delivered vaginally. Normal deliveries constituted $67 \%$ and LSCS to remaining 33\% Normal delivery: Vaginal delivery of treated as well as untreated IUGR babies in these patients was attempted with utmost care. With a reassuring fetal heart rate pattern, vaginal delivery was attempted. In the $1^{\text {st }}$ stage of labour fetal heart was auscultated every $20 \mathrm{~min}$ and CST was performed twice which was found satisfactory. In $2^{\text {nd }}$ stage of labour, the fetal heart was auscultated more often as in after every contraction. $2^{\text {nd }}$ stage of labour was not allowed to exceed rather we prefer to cut short it so that stress over IUGR babies is minimized. As a result, 17 patients successfully delivered vaginally. LSCS: fetal growth restriction is commonly the result of placental insufficiency due to faulty maternal perfusion, ablation of the functional placenta or both. If present, these conditions are likely aggravated by labour. Equally diminished amniotic fluid volume increases the likelihood of cord compression during labour. So, for these reasons, a woman with a suspected growth-restricted fetus should undergo high-risk intrapartum monitoring. For these and other reasons like meconium-stained liquor and fetal distress, cesarean delivery was performed in 8 patients.There was a significant rise in maternal weight after the treatment of one month. The average rise in maternal weight was $2.22 \mathrm{kgs}$. According to Ashtang Hrudaya, Garbhini comes under the category of who should be administered the Santarpan (growth-promoting) type of treatment. When there is Krushta (low maternal weight) the need for Bruhan should be emphasized more. In our study, the drugs chosen that is Ashwagandha and Yashtimadhu with Sharkarayukt Dugdha has the property of Bruhana. Due to their property of being Guru, Snigdha, Sheet, Madhura and Vataghna it has reduced debility and helped in increasing maternal weight by promoting growth. In the present study already diagnosed, IUGR patients were taken, where main causes observed were nutritional deficiency, stress which restricts the growth of baby. There was a significant rise in abdominal girth after the treatment of one month. Average abdominal girth has significantly increased from 78.92 to $85.32 \mathrm{~cm}$. Considering Before Treat- ment \& After Treatment analysis of the patients with an ideal weight according to SHEPHERD'S CHART there is an increase in EFW though it may not reach up to normal values. From this comparison it is observed that, in 9 patients there is increase in EFW by $600-650 \mathrm{gms}$, in 7 patients it is $700-750 \mathrm{gms}$. In 4 patients it is 800 gms. In 2 patients it is between the range 300-350 gms. And in 3 patients it is near about $1 \mathrm{~kg}$. In IUGR babies growth is restricted and normal weight is not achieved according to the Shepherds chart. Causes of IUGR are teenaged or elderly, hardworking women, poor social class etc. There was consistent weight gain by fetus, for the Pushti and Abhivrudhi of a fetus who is affected by Vayu and has dried up and who does not fill mother's abdomen properly was treated by Aushadi Gunas like Madhur, Sheet, Guru, Snigdha to achieve properties like Bruhan, Rasayan, Vatagnah etc. In Samprapti of IUGR there is Dhatukshaya due to Dhatuagnimandhya and so Rasadidhatuasarta. By Deepaniya Karma of Ashwagandha, Dhatvagni can be reignited and Yashtimadhu helps in nourishing the fetus. Weight gain is achieved by the fetus when there is proper Poshan, in the $2^{\text {nd }}$ and $3^{\text {rd }}$ trimester Poshan is achieved by Kedarkuliya Nyay. Poshan is done by Bruhana. Bruhaniya Dravya contains two Mahabhutas Pruthvi and Jal and the medicine in the study contains both the Mahabhutas. IUGR which is caused due to obstruction in Apara and Garbhnabhinadi, Tikta rasa helps to remove the obstruction and thus the fetus can get its maximum Poshan and complications of LBW can be prevented. So, due to all these properties may weight gain was seen by the fetus at the end of treatment. We found a maximum no. of the patient in a group of Gestational Age 28 to 32 wks because, in 9month pregnancy, growth and development of foetal dhatus occurs in the second and third trimester of pregnancy. So that in the present study most of the patients had diagnosed with IUGR in G.A. of 28 to 32 wks. There was no significant effect on liquor status during Treatment. The observation chart is attached with it. Out of 25 patients, 14 babies birth weight is equal to \& more than $2.5 \mathrm{kgs}, 11$ babies are having birth weight less than $2.5 \mathrm{kgs}$. 
There was a significant rise in fundal height after the treatment of one month. Average fundal height has significantly increased from 27.96 to 32.68 . Not a significant effect was observed on $\mathrm{Hb} \%$ levels. No specific change on any Lakshanas like Agnimandya, Malavastambha, Needra etc.

\section{CONCLUSION}

In the present study, it has been seen that Ashwagandha Vati \& Yashtimadhu Vati with Sharkara Yukta Dugdha gave promising results as these drugs possess qualities like Balya, Brihaniya, Rasayan, Deepaniya, \& Pachaniya. There were no untoward side effects of Ashwagandha Vati, Yashtimadhuvati with Sharkarayukta Dugdha neither in pregnant mother nor on fetus in utero. Aahar Vihar, Yonigata Strav were the Hetus found in the study.

The incidence of IUGR was maximally seen in the gestational age group 28-32 wks. The incidence of IUGR seen in the age group 21-25 yrs. The majority of IUGR cases are found in Pitta-Vatanubandhi Prakruti.

Primi gravida patients were mostly affected. The average maternal weight, abdominal girth and fundal height are significantly increased. The average weight gain seen in the foetus was around 600-700 gms. There was an average effect on the outcome (birth weight) $44 \%$ of cases were below $2.5 \mathrm{~kg}$. This Ayurvedic formulation for IUGR is effective. It can provide a safe reliable \& economical alternative to the available mode of management.

According to Ayurveda, IUGR is similar to that of Upavishtak \& Nagodar \& Samprapti of Upavishtak \& Nagodar is Strotorodha \& Hina Upachaya (malnutrition), as Ashwagandha, Yashtimadhu \& Sharkarayukta Dugdha are Balya, Brihaniya, Jeevaniya helps in increase in bulk or mass of the fetus. Ushnaveerya of Ashwagandha helps in Vatashaman as well as it removes the Strotorodha \& thus it improves the placental circulation. Further research needs to be done to validate the use of this formulation as an alternative management of IUGR.

\section{REFERENCES}

1. Vaidya Bhagavan Das \& Dr R.K. Sharma, Charaka Samhita with English Translation based on Chakrapani Datta's Ayurveda Deepika, 6th Edn., Choukhamba Sanskrit Series, Varanasi, (1999).

2. Pt. Sri.BrahmaSankaraMisra, Bhava Prakasha of Bhavamisra with Vidyotini Hindi Commentary, 5th Edn., Choukamba Sanskrit Samsthan, Varanasi, (1993).

3. Adhamalla's Dipika, and Kasiram's Gudhardha Dipika, Sarangadhara Samhita with Commentary, (Hindi); Choukhambaorientalia, Varanasi. (2000).

4. Yadavji Trikamji, Susruta Samhita with DalhanajNibandhaSangraha and Nyaya Chandrika, Panjika of Sri. Gayadasacharya on NidanaSthana, Choukamba Orientalia, Varanasi. (2002).

5. Bramhanand Tripathi, Charaka Samhita with Hindi Vyakhya, ChoukhambaSurbharatiPrakashan, Varanasi, (2006).

6. K.C. Chunekar, Bhavprakash Nighantu with Hindi Vyakhya, Choukhamba Bharati Academy, (2004)

7. Vaidya Lakshmipati Sastry, Yogaratnakara with Vidyotini Hindi Commentary, 7th Edn., Choukamba Sanskrit Samsthan, Varanasi, (2002).

8. Pandey Ganga Sahaya and Chunekar Chandra Krishna, Bhavprakash Nighantu, Varanasi, Chaukhabha Bharati Academy Publishers and Distributor of Monumental Treaties of the east, 2006.

9. Tewari Premvati, AyurvediyaPrasuti Tantra evamStreeroga, Part 1, Varanasi, Chaukhambha Orientalia, 2007.

10. Dr Gyanendra Pandey, DravyagunaVijnana, 3rd edition, Vol 1,2,3, Varanasi, chowkhambakrishnadas academy, 2005.

11. Fernando Arias, Practical Guide to High-Risk Pregnancy and Delivery, 3rd edition, Kundli, Elsevier, 2011.

12. 12.Harry Oxorn, Human Labor and Birth, 5th edition, New Delhi, Tata McGraw- Hill, 2010.

13. Clinical Obstetrics and Gynaecology, 2nd edition, Elsevier, 2009.

14. Williams Obstetrics, 23rd edition, United States of America, The McGraw -Hill, 2010.

15. Clinical cases in Obstetrics and Gynecology, 4th edition, Ahmedabad, Arihant Publishers, 2011.

16. FOGSI, Do's and Don'ts in Obstetrics and Gynecology Practice, 1st edition, Jaypee Brothers Medical Publishers, 2012. 
17. Case Discussions in Obstetrics and Gynecology, 1st edition, New Delhi, Jaypee Brothers Medical Publishers, 2011.

18. Richa Saxena, Bedside Obstetrics and Gynecology, 1st edition, New Delhi, Jaypee Brothers Medical Publishers, 2010

19. D.C. Dutta, Textbook of Obstetrics, 7th edition, London, New Central Book Agency, 2010.

20. WORLD HEALTH ORGANIZATION, Healthy Eating during Pregnancy and Breastfeeding, Europe, WHO Regional Office, 2001.

21. www.google.com

22. www.wikepedia.com

\section{Source of Support: Nil}

\section{Conflict of Interest: None Declared}

How to cite this URL: Priti Pimpalshende \& Mrudula B. Kulkarni: Efficacy Of Ashwagandha And Yashtimadhu Vati With Sharkarayukta Dugdha In Intrauterine Growth Retardation (IUGR). International Ayurvedic Medical Journal \{online\} 2021 \{cited July 2021\} Available from: http://www.iamj.in/posts/images/upload/1383_1392.pdf 